\title{
Correction to: The 'can do, do do' concept in COPD; quadrant interpretation, affiliation and tracking longitudinal changes
}

Alex J. van 't Hul ${ }^{1 *}$, Noortje H. Koolen', Jeroen W. van Hees ${ }^{1}$, Bram van den Borst ${ }^{1}$ and Martijn A. Spruit 2,3,4

Correction to: Respiratory Research (2020) 21:112

https://doi.org/10.1186/s12931-020-01375-3

Following publication of the original article [1], the authors identified a mistake in the author names, as both forename and initials were stated.

Initially published author names:

A. J. Alex van 't Hul, E. H. Noortje Koolen, H. W. Jeroen van Hees, B. Bram van den Borst and M. A. Martijn Spruit

Correct author names:

Alex J. van 't Hul, Noortje H. Koolen, Jeroen W. van Hees, Bram van den Borst, Martijn A. Spruit.

The original article has been corrected.

\section{Author details}

${ }^{1}$ Department of Pulmonary Diseases, Radboud University Medical Center, 6525 GA Nijmegen, The Netherlands. ${ }^{2}$ Department of Research and Education, CIRO+, Centre of Expertise for Chronic Organ Failure, CIRO, 6085 NM Horn, The Netherlands. ${ }^{3}$ Department of Respiratory Medicine, Maastricht University Medical Centre, NUTRIM School of Nutrition and Translational Research in Metabolism, 6229 HX Maastricht, The Netherlands.

${ }^{4}$ REVAL-Rehabilitation Research Center, BIOMED-Biomedical Research Institute, Faculty of Rehabilitation Sciences, Hasselt University, 3590 BE

Diepenbeek, Belgium.

Published online: 23 May 2020

\section{Reference}

1. van 't Hul A, et al. The 'can do, do do' concept in COPD; quadrant interpretation, affiliation and tracking longitudinal changes. Respir Res. 2020; 21:112. https://doi.org/10.1186/s12931-020-01375-3.

The original article can be found online at https://doi.org/10.1186/s12931020-01375-3.

* Correspondence: alex.vanthul@radboudumc.nl

${ }^{1}$ Department of Pulmonary Diseases, Radboud University Medical Center, 6525 GA Nijmegen, The Netherlands

Full list of author information is available at the end of the article

(c) The Author(s). 2020 Open Access This article is licensed under a Creative Commons Attribution 4.0 International License, which permits use, sharing, adaptation, distribution and reproduction in any medium or format, as long as you give appropriate credit to the original author(s) and the source, provide a link to the Creative Commons licence, and indicate if changes were made. The images or other third party material in this article are included in the article's Creative Commons licence, unless indicated otherwise in a credit line to the material. If material is not included in the article's Creative Commons licence and your intended use is not permitted by statutory regulation or exceeds the permitted use, you will need to obtain permission directly from the copyright holder. To view a copy of this licence, visit http://creativecommons.org/licenses/by/4.0/ The Creative Commons Public Domain Dedication waiver (http://creativecommons.org/publicdomain/zero/1.0/) applies to the data made available in this article, unless otherwise stated in a credit line to the data. 